\title{
ANALISIS KEMAMPUAN BERPIKIR KRITIS MATEMATIS DITINJAU DARI KEMANDIRIAN BELAJAR SISWA KELAS XI MELALUI PENDEKATAN METAKOGNITIF
}

\author{
Ajeng Yulia Rahmawati ${ }^{1}$, Euis Eti Rohaeti ${ }^{2}$, Anik Yuliani ${ }^{3}$ \\ 1,2,3Program Studi Pendidikan Matematika IKIP Siliwangi \\ ${ }^{1}$ halloajeng@gmail.com, ${ }^{2}$ e2rht@yahoo.com, ${ }^{3}$ anik_yuliani070886@yahoo.com
}

\begin{abstract}
This research is a quantitative research that aims to (1) examine the differences of students 'mathematical critical thinking ability in terms of self regulated learning which gain learning with metacognitive approach and students who only get ordinary learning (2) examine the influence of self regulated learning on students' mathematical critical thinking ability and (3) to describe students' mathematical critical thinking skills in terms of self regulated learning. Subjects in this research were students of class XI in MAN 1 Cimahi with the subject amounted to 64 students consisting of the control class and experimental class. Subjects were divided into three groups based on self-regulated learning level, specifically high level, medium level, and low level. Based on the results of the research, it's found that (1) the ability of mathematical critical thinking in the experimental class is better than the mathematical critical thinking ability of the control class (2) the students' self-regulated learning of the experimental group positively influences the critical thinking skills of mathematics (3) The students of high level already able the indicators of critical thinking ability. The students of medium level are still experiencing errors in the algorithm resulting in incorrect results and conclusions. The Students of low level have not been able to meet the indicators of critical mathematical thinking ability.
\end{abstract}

Keywords: Mathematical Critical Thinking, Self-Regulated Learning, Metacognitive Approach

\begin{abstract}
Abstrak
Penelitian ini merupakan penelitian kuantitatif yang bertujuan untuk (1) menguji perbedaan kemampuan berpikir kritis matematis siswa ditinjau dari kemandirian belajar yang memperoleh pembelajaran dengan pendekatan metakognitif dan siswa yang hanya memperoleh pembelajaran biasa (2) menguji pengaruh kemandirian belajar terhadap kemampuan berpikir kritis matematis siswa dan (3) mendeskripsikan kemampuan berpikir kritis matematis siswa ditinjau dari kemandirian belajar. Subjek dalam penelitian ini adalah Siswa kelas XI di MAN 1 Cimahi dengan berjumlah sebanyak 64 orang yang terdiri atas kelas kontrol dan kelas eksperimen. Subjek dibagi atas tiga kelompok berdasarkan pengisian angket yaitu siswa pada kelompok kemandirian belajar tinggi, sedang, dan rendah. Berdasarkan hasil penelitian didapatkan bahwa (1) kemampuan berpikir kritis matematis siswa kelas eksperimen lebih baik dari kemampuan berpikir kritis matematis kelas kontrol (2) kemandirian belajar siswa kelompok eksperimen berpengaruh positif terhadap kemampuan berpikir kritis matematis (3) Siswa pada kelompok kemandirian belajar tinggi sudah mampu memenuhi indikator kemampuan berpikir kritis matematis. Siswa pada kelompok kemandirian belajar sedang masih mengalami kekeliruan dalam algoritma sehingga menghasilkan hasil dan kesimpulan yang kurang tepat. Siswa pada kemandirian belajar rendah belum mampu memenuhi indikator kemampuan berpikir kritis matematis.
\end{abstract}

Kata Kunci: Berpikir Kritis Matematis, Kemandirian Belajar, Pendekatan Metakognitif.

How to cite: Rahmawati, A. Y., Rohaeti, E. E., \& Yuliani, A. (2018). Analisis Kemampuan Berpikir Kritis Matematis Ditinjau dari Kemandirian Belajar Siswa Kelas XI Melalui Pendekatan Metakognitif. JPMI - Jurnal Pembelajaran Matematika Inovatif, 1 (4), 607-616. 


\section{PENDAHULUAN}

Kemampuan matematis merupakan kemampuan untuk menghadapi permasalahan, baik dalam matematika ataupun kehidupan nyata. Menurut NCTM (Yuliani, 2015) Kemampuan matematis yang penting dimiliki oleh siswa terdiri dari penalaran, komunikasi, pemecahan masalah, pemahaman konsep, pemahaman matemati. Kemampuan berpikir kritis dan kreatif diperlukan untuk menumbuhkan kemampuan penalaran. Sebagaimana yang disampaikan Kemendikbud (2013) dalam pengembangan kurikulum 2013 bahwa kompetensi masa depan yang harus dimiliki siswa antara lain: kemampuan komunikasi, kemampuan berpikir jernih dan kritis, kemampuan mempertimbangkan segi moral suatu permasalahan, kemampuan menjadi warga negara yang bertanggung jawab, memiliki rasa pengertian dan toleransi terhadap pandangan yang berbeda, memiliki kesiapan untuk bekerja, memiliki kecerdasan sesuai dengan bakat atau minatnya, dan memiliki rasa tanggung jawab terhadap lingkungan.

Kemampuan berpikir kritis merupakan salah satu kemampuan dalam matematika yang perlu dikembangkan kepada peserta didik dalam pembelajaran matematika (Hidayat, 2011; 2012; Sumarmo, Hidayat, Zukarnaen, Hamidah, \& Sariningsih, 2012; Tresnawati, Hidayat, \& Rohaeti, 2017). Beberapa ahli mendefinisikan kemampuan berpikir kritis secara beragam. Menurut Ennis (Hendriana, Sumarmo, \& Rohaeti, 2013) mendefinisikan berpikir kritis merupakan berpikir secara reflektif yang beralasan dan difokuskan pada penetapan apa yang dipercayai atau yang dilakukan. Ahli lain, Glaser (Hendriana, Sumarmo \& Rohaeti, 2013; Rohaeti, 2010) menyatakan bahwa berpikir kritis matematis memuat kemampuan dan disposisi yang dikombinasikan dengan pengetahuan, penalaran matematis, dan strategi kognitif yang sebelumnya, untuk menggeneralisasikan, membuktikan, mengakses situasi matematis secara reflektif. Berpikir kritis matematis sebagai proses berpikir secara beralasan dan reflektif yang difokuskan pada pengambilan keputusan, memecahkan masalah, menganalisis asumsi sesuai dengan apa yang diyakini dan dilakukan.

Kemampuan berpikir kritis matematis bukan hal baru dalam kajian pembelajaran matematika. Berdasarkan penelitian sebelumnya yang dilakukan oleh TIM Survey IMSTEP-JICA (Fachrurazi, 2011) di kota Bandung menemukan sejumlah kegiatan yang dianggap sulit oleh siswa untuk mempelajarinya dan oleh guru untuk mengajarkannya. Kesulitan tersebut antara lain tentang pembuktian pemecahan masalah yang memerlukan penalaran matematis, menemukan, generalisasi atau konjektur, dan menemukan hubungan antara data-data atau fakta yang diberikan. Kegiatan-kegiatan yang dianggap sulit tersebut, jika kita perhatikan merupakan kegiatan yang menuntut kemampuan berpikir kritis.

Dalam pembelajaran matematika agar kemampuan matematis tumbuh dengan baik khususnya kemampuan berpikir kritis matematis, siswa perlu memiliki aspek afektif dalam belajar yang dinamakan dengan kemandirian belajar. Menurut Hargis dan Kerlin (Hendriana, Rohaeti, \& Sumarmo, 2017) mendefinisikan kemandirian belajar sebagai proses perancangan dan pemantauan diri yang seksama terhadap proses kognitif dan afektif dalam menyelesaikan suatu tugas akademik. Berdasarkan pendapat para ahli, Sumarmo (Budiyanto \& Rohaeti, 2012; Hidayat \& Sumarmo, 2013) merangkum beberapa indikator kemandirian belajar sebagai berikut: (a) Inisiatif belajar, (b) Mendiagnosa kebutuhan belajar, (c) Menetapkan target dan tujuan belajar, (d) Memilih dan menerapkan Strategi Belajar, (e) Memandang kesulitan sebagai tantangan, (f) Memanfaatkan dan mencari sumber yang relevan, (g) Memonitor, mengatur dan mengontrol kemajuan belajar, (h) Mengevaluasi proses dan hasil belajar, (i) Memiliki konsep diri (self-concept). 
Berdasarkan hasil observasi awal mengenai kemampuan berpikir kritis dan juga kemandirian belajar matematika siswa Madrasah Aliyah atau sederajat dengan SMA yang dilakukan terhadap 34 orang siswa kelas XI MA Negeri 1 Cimahi, diperoleh hasil bahwa kemampuan berpikir kritis matematis siswa dibawah angka 50\% hanya mencapai 30,8\%, dan kemandirian belajar siswa diperoleh 36,21\% siswa dengan kemandirian belajar tinggi, 35, 46\% siswa dengan kemandirian sedang, dan 28,33\% siswa dengan kemandirian belajar rendah. Hal tersebut mengindikasi bahwa kemampuan berpikir kritis matematis dan kemandirian belajar matematika siswa kelas XI MA Negeri 1 Cimahi belum optimal sehingga perlu memperbaiki proses pembelajaran. Mengembangkan kemandirian belajar siswa akan sulit dicapai jika hanya menerapkan pembelajaran biasa yang bersifat konvensional. Hal ini tentu akan berdampak pada kemampuan berpikir kritis matematis siswa.

Pendekatan pembelajaran matematika yang diharapkan mampu dapat menumbuhkan kemandirian belajar dan melatih kemampuan berpikir kritis siswa adalah pendekatan metakognitif. Kuhn (Chrissanti \& Widjajanti, 2015) menjelaskan kemampuan metakognitif merupakan kemampuan kognitif yang dipandang paling relevan dengan kemampuan berpikir kritis. Hal ini disebabkan bahwa kemampuan metakognitif merupakan kemampuan berpikir derajat dua yang memerlkan pengetahuan tentang pengetahuannya sendiri dan pengetahuan orang lain. Menurut Suzana (Solikhah, Winarti, \& Kurniasih, 2014) menjelaskan bahwa pembelajaran dengan pendekatan metakognitif sebagai pembelajaran yang menanamkan kesadaran bagaimana merancang, memonitor, serta mengontrol, tentang apa yang mereka ketahui; apa yang diperlukan untuk mengerjakan dan bagaimana melakukannya.

Melalui pendekatan metakognitif, siswa diajak untuk diajak untuk menyadari kekurangan serta kelebihan yang dimilikinya dalam mempelajari matematika serta bagaimana mengatasinya. Pembelajaran dengan pendekatan ini cenderung untuk melibatkan siswa secara aktif sebagai pusat pembelajaran dibanding dengan pembelajaran konvensional. Siswa dapat secara aktif mengontrol proses berpikir dan belajarnya. Kegiatan inilah yang diharapkan dapat mengoptimalkan kemandirian belajar siswa.

Cardele (Susilawati, 2014) menjelaskan bahwa pendekatan metakognitif terdiri dari tiga tahap: (a) Tahap diskusi awal, penanaman konsep diawali dari membaca, memahami permasalahan, menjelaskan konsep-konsep secara relevan sesuai dengan bahasa mereka sendiri, dan berusaha mencari solusi permasalah tersebut (b) Tahap Kemandirian, pada tahap ini siswa bekerja secara mandiri untuk menyelesaikan soal-soal. Guru hanya memberikan feedback metakognisi yang akan menuntun siswa mengoreksi cara berpikirnya. (c) Tahap Refleksi dan penyimpulan, pada tahap ini tidak hanya dilakukan oleh guru tetapi dilakukan oleh siswa. Refleksi yang dilakukan oleh guru bertujuan sebagai pemantapan konsep dan aplikasi konsep lebih luas, sehingga belajar siswa menjadi lebih bermakna. Sedangkan refleksi yang dilakukan oleh siswa lebih mengarah pada apa yang telah mereka pahami setelah mendapatkan pembelajaran sehingga memungkinkan siswa untuk dapat mengaplikasikan konsep tersebut dalam masalah lebih luas.

Berdasarkan uraian yang telah disampaikan, penelitian ini bertujuan untuk (1) menguji perbedaan kemampuan berpikir kritis matematis siswa ditinjau dari kemandirian belajar yang memperoleh pembelajaran dengan pendekatan metakognitif dan siswa yang hanya memperoleh pembelajaran biasa (2) menguji pengaruh kemandirian belajar terhadap kemampuan berpikir kritis matematis siswa dan (3) mendeskripsikan kemampuan berpikir kritis matematis siswa ditinjau dari kemandirian belajar. 


\section{METODE}

Penelitian ini merupakan penelitian kuantitatif dengan jenis penelitian eksperimen semu. Desain penelitian yang digunakan dalam penelitian ini adalah Posttest Only Control Group Design. Metode pengumpulan data dilakukan dengan tes dan nontes. Instrumen tes berupa soal kemampuan berpikir kritis yang sudah di ujikan validitas, realibilitas, daya pembeda dan indeks kesukarannya. Sedangkan instrumen nontes berupa angket kemandirian belajar matematika siswa.

Populasi dalam penelitian ini adalah seluruh siswa kelas XI MAN 1 Cimahi, tahun ajaran 2017/2018. Penentuan sampel pada penelitian ini menggunakan teknik cluster random sampling. Berdasarkan prosedur cluster random sampling maka diperoleh kelas XI MIA 2 sebagai kelompok eksperimen dan kelas XI MIA 3 sebagai kelompok kontrol. Selanjutnya, Kelas XI MIA 2 yang merupakan kelompok eksperimen diberi pembelajaran matematika melalui pendekatan metakognitif, sedangkan kelas XI MIA 3 yang merupakan kelas kontrol diberi pembelajaran biasa. Dalam penentuan subjek penelitian siswa diberikan angket kemandirian belajar kemudian dikelompokan menjadi 3 kelompok yakni kelompok kemandirian belajar tinggi, kelompok kemandirian belajar sedang, dan kelompok kemandirian belajar rendah untuk dianalisis kemampuan berpikir kritis matematiknya.

Hasil tes kemampuan berpikir kritis matematik dan angket kemandirian belajar siswa dianalisis untuk menguji kebenaran hipotesis penelitian. Uji perbedaan rata-rata untuk menguji perbedaan kemampuan berpikir kritis matematik siswa yang memperoleh pembelajaran dengan pendekatan metakognitif dan siswa yang memperoleh pembelajaran konvensional. Kemudian dilakukan analisis regresi untuk menguji pengaruh kemandirian belajar terhadap kemampuan berpikir kritis matematik siswa yang memperoleh pembelajaran dengan pendekatan metakognitif, dan analisis kualitatif digunakan untuk memperoleh deskripsi kemampuan berpikir kritis matematik siswa ditinjau dari kemandirian belajar.

\section{HASIL DAN PEMBAHASAN}

\section{Hasil}

Pembelajaran yang dilakukan dalam penelitian ini yaitu pembelajaran melalui pendekatan metakognitif untuk kelas eksperimen dan pembelajaran biasa pada kelompok kelas kontrol. Materi yang diajarkan pada penelitian ini adalah materi limit fungsi aljabar. Selanjutnya data yang dideskripsikan pada bagian ini adalah hasil tes yang dicapai siswa dan hasil angket kemandirian belajar matematik yang dikumpulkan sesudah diberikan perlakuan. Berikut adalah data hasil postes kemampuan berpikir kritis matematis siswa pada kelas eksperimen dan kelas kontrol yang disajikan dalam Tabel.

Tabel 1. Skor Rata-Rata Postes Kemampuan Berpikir Kritis pada Kelas Eksperimen dan

\begin{tabular}{ccc} 
& Kelas Kontrol & \\
\hline Statistik Deskriptif & Eksperimen & Kontrol \\
\hline Rata-rata & 17,85 & 12,87 \\
Standar deviasi & 4,46 & 4,82 \\
Skor tertinggi & 26 & 25 \\
Skor terendah & 10 & 6 \\
Skor maksimum teoritik & 30 & 30 \\
Skor minimum teoritik & 0 & 0 \\
\hline
\end{tabular}


Pada Tabel 1. tampak bahwa pada kelas eksperimen yang diberikan perlakuan dengan pembelajaran melalui pendekatan metakognitif dan kelas kontrol yang diberikan pembelajaran biasa memiliki skor rata-rata yang berbeda. Pada kelas eksperimen skor rata-rata hasil postes kemampuan berpikir kritis matematis adalah 17,85. Sedangkan pada kelas kontrol skor ratarata hasil postes kemampuan berpikir kritis matematis adalah 12,87. Dari hasil tabel tersebut dijelaskan bahwa kelas eksperimen yang diberikan perlakuan dengan pembelajaran melalui pendekatan metakognitif memiliki skor rata-rata lebih besar daripada kelas kontrol dengan pembelajaran biasa.

Uji perbedaan rata-rata digunakan untuk menguji perbedaan kemampuan berpikir kritis matematis siswa yang diberikan pembelajaran melalui pendekatan metakognitif dan kemampuan berpikir kritis matematis siswa melalui pembelajaran biasa. Uji perbedaan ratarata yaitu uji parametrik jika kedua sampel berdistribusi normal. Uji perbedaan rata-rata pada penelitian ini dilakukan dengan menggunakan bantuan software SPSS 22 dimana untuk data postes kemampuan berpikir kritis matematis digunakan uji t, signifikansi yang diambil yaitu one tailed dengan uji pihak kanan dibagi 2 pada sig two tailed. Sampel data pada penelitian ini berdistribusi normal dan homogen sehingga dapat diuji perbedaan rata-ratanya. Berikut adalah Tabel hasil uji rata-rata data postes kemampuan berpikir kritis matematis.

Tabel 2. Hasil Uji Perbedaan Rata-Rata Kemampuan Berpikir Kritis Matematis

\begin{tabular}{cccccccc}
\hline Kelas & $\mathrm{N}$ & $\mathrm{X}$ & $\mathrm{S}$ & $\mathrm{T}_{\text {hit }}$ & $\begin{array}{c}\text { Sig } \\
\text { (2-tailed) }\end{array}$ & $\begin{array}{c}\text { Sig } \\
\text { (1-tailed) }\end{array}$ & Interprestasi \\
\hline Eksperimen & 34 & 17,9 & 4,46 & 4,33 & 0,000 & 0 & $\mathrm{H}_{\mathrm{o}}$ ditolak \\
Kontrol & 31 & 12,9 & 4,82 & & & & \\
\hline
\end{tabular}

Berdasarkan tabel perhitungan Tabel 2. di dapatkan nilai signifikan sebesar 0,000. Jelas jika sig $<0,005$ maka $\mathrm{H}_{\mathrm{o}}$ ditolak. Jadi rata-rata kemampuan berpikir kritis siswa yang pembelajarannya menggunakan pendekatan metakognitif lebih baik daripada yang menggunakan pembelajaran biasa.

Selanjutnya dilakukan uji regresi guna untuk menguji pengaruh kemandirian belajar terhadap kemampuan berpikir kritis matematis siswa. Berdasarkan hasil perhitungan berbantuan software SPSS 22 didapatkan hasil persamaan regresi $Y=85,765+1,504 X$. Variabel $X$ menyatakan kemandirian belajar dan $Y$ menyatakan kemampuan berpikir kritis matematis. Persamaan regresi tersebut menunjukkan bahwa untuk koefisien regresi $X$ sebesar 1,504 menyatakan bahwa setiap penambahan $1 \%$ skor kemandirian belajar , maka nilai kemampuan berpikir kritis matematis siswa bertambah sebesar 1,504. Hal tersebut bernilai positif, sehingga dapat dikatakan bahwa arah pengaruh kemandirian belajar terhadap kemampuan berpikir kritis adalah positif. Berdasarkan nilai $t_{\text {hitung }} 4,618>t_{\text {tabel }} 2,037$ dengan signifikansi 0,000 yang berarti $\mathrm{H}_{\mathrm{o}}<0,05$ yang berarti $\mathrm{H}_{\mathrm{o}}$ ditolak sehingga dapat disimpulkan maka ada pengaruh kemandirian belajar $(X)$ terhadap kemampuan berpikir kritis matematis $(Y)$. Selanjutnya berdasarkan perhitungan diperoleh koefisien korelasi sederhana $r=0,632$ dengan koefisien determinasi yakni $r^{2}=0,40=40 \%$.

Selain menguji perbedaan rata-rata untuk membandingkan kemampuan berpikir kritis matematis siswa yang memperoleh pembelajaran dengan pendekatan metakognitif dengan yang memperoleh pembelajaran biasa, serta melihat pengaruh kemandirian belajar terhadap 
kemampuan berpikir kritis matematis siswa, pada penelitian ini juga akan dilihat bagaimana kemampuan berpikir kritis matematis siswa ditinjau dari kemandirian belajarnya.

Tabel 3. Hasil Tes Kemampuan Berpikir Kritis Matematis Berdasarkan Kelompok Kemandirian Belajar Pada Kelas Eksperimen

\begin{tabular}{cc}
\hline $\begin{array}{c}\text { Kelompok } \\
\text { Kemandirian Belajar }\end{array}$ & Skor Rata-Rata \\
\hline Tinggi & 20,73 \\
Sedang & 17,42 \\
Rendah & 15,45 \\
\hline Total & $\mathbf{5 3 , 6}$ \\
\hline
\end{tabular}

\section{Pembahasan}

Hasil analisis data dari uji perbedaan dua rata-rata didapatkan bahwa skor rata-rata kemampuan berpikir kritis matematis kelas eksperimen sebesar 17,84, dan kelas kontol sebesar 12,87 dengan sig $<0,005$ maka Ho ditolak. Jadi rata-rata kemampuan berpikir kritis siswa yang pembelajarannya menggunakan pendekatan metakognitif lebih baik daripada yang menggunakan pembelajaran biasa. Hal tersebut dikarenakan pendekatan metakognitif sangat baik diterapkan dalan proses pembelajaran di kelas, karena dengan menerapkan pendekatan metakognitif terdapat pengaruh terhadap kemampuan tingkat tinggi siswa. Pendekatan metakognitif lebih menekankan pada keaktifan siswa berpikir siswa sehingga dengan menerapkan berbagai strategi metakognitif, siswa secara aktif telah membangun pengetahuannya serta mengembangkan kemampuan berpikirnya yang kemudian memicu peningkatan kemampuan berpikir kritis matematis siswa serta kemampuan berpikir kritis matematis siswa yang menggunakan pendekatan metakognitif lebih baik dibandingkan dengan yang menggunakan pembelajaran konvensional (Chrissanti \& Widjajanti, 2015; Iskandar, 2014; Noordyana, 2016)

Selain itu, dari hasil analisis regresi diketahui kemandirian belajar berpengaruh terhadap kemampuan berpikir kritis matematis siswa sebesar 40\% melalui regresi $Y=85,765+$ $1,504 X$, sedangkan $60 \%$ sisanya ditentukan oleh faktor lain misalnya, model dan pendekatan pembelajaran yang diterapkan. Sejalan dengan penelitian Noto, Tonah, \& Hernati (2015) yang mengungkapkan bahwa aktivitas dalam pendekatan metakognitif berpengaruh terhadap kemampuan penalaran matematis yang dimana dalam penalaran matematis dibutuhkan untuk menumbuhkan kemampuan berpikir kritis matematis, dan untuk pengaruh tidak langsungnya dapat dilihat dari aktivitas siswa dalam pembelajaran dengan menggunakan pendekatan metakognitif melalui kemandirian belajar terhadap kemampuan berpikir kritis siswa. Dengan demikian, jika siswa memiliki kemandirian belajar yang tinggi maka siswa tersebut mampu meningkatkan kemampuan berpikir kritis matematisnya. Selain itu, faktor lainnya yang dapat meningkatkan kemampuan berpikir kritis siswa juga terhadap kemandirian belajar dikarenakan siswa diberikan pembelajaran melalui pendekatan metakognitif. Jadi pada pembelajaran yang menggunakan pendekatan metakognitif, siswa dituntut untuk secara aktif mengembangkan kemampuan berpikir kritisnya secara mandiri melalui permasalahanpermasalahan yang disajikan melalui LKS yang diberikan. 
Berikut adalah analisis deskriptif kemampuan berpikir kritis matematis siswa pada kelas eksperimen ditinjau dari kemandirian belajarnya.

\section{a. Analisis Kemampuan Berpikir Kritis Siswa dengan Kemandirian Belajar Tinggi}

Berdasarkan Tabel 3. pada bagian hasil menunjukkan skor kemampuan berpikir kritis matematis kelompok kemandirian belajar tinggi pada kelas eksperimen. Pada tabel tersebut terlihat skor rata-rata kemampuan berpikir kritis matematis yang dimiliki siswa sebesar 20,73. Hal ini dapat dikatakan baik. Berikut adalah salah satu jawaban siswa kelompok kemandirian belajar tinggi pada soal no.6 yang merupakan soal sukar dengan indikator evaluasi

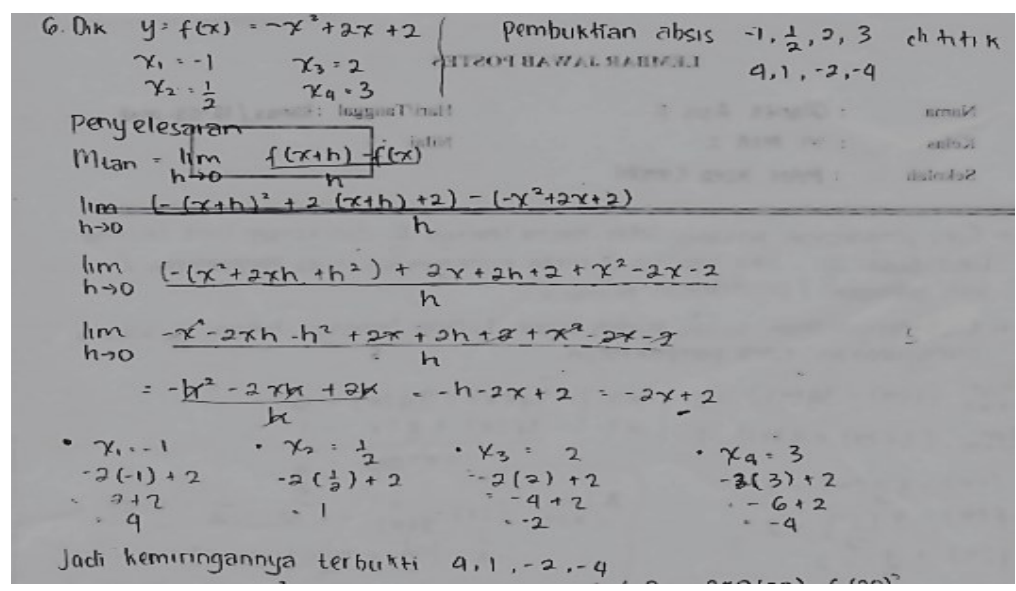

Gambar 1. Jawaban Siswa Kelompok Kemandirian Belajar Tinggi

Pada soal nomor 6 merupakan soal yang sukar dimana banyak siswa kesulitan dalam menjawab soal nomor 6 tersebut. Pada Gambar 1. menunjukkan bahwa salah satu siswa pada kelompok kemandirian belajar tinggi, mampu mengusulkan dan mengidentifikasi masalah matematika yang terdapat pada soal. Kemudian subjek tersebut mampu mengusulkan berupa ide/konsep yang relevan, selanjutnya mampu membuktikan dan mengevaluasi pernyataan pada soal yang diberikan tersebut. Jadi dapat dikatakan pada kelompok kemandirian belajar tinggi memiliki kemampuan berpikir kritis yang baik. Hal tersebut dikarenakan kemandirian belajar berpengaruh terhadap kemampuan berpikir kritis matematis. Pada dasarnya bahwa individu yang memiliki kemandirian belajar yang tinggi cenderung belajar lebih baik, mampu memantau, mengevaluasi, mengatur belajarnya secara efektif (Budiyanto \& Rohaeti, 2012; Jumaisyaroh, Napitupulu, \& Hasratuddin, 2014).

\section{b. Analisis Kemampuan Berpikir Kritis Siswa dengan Kemandirian Belajar Sedang}

Pada Tabel 3. tersebut terlihat skor rata-rata kemampuan berpikir kritis matematis yang dimiliki siswa sebesar 17,42. Hal ini dapat dikatakan bahwa kemampuan berpikir kritis matematis siswa pada kelompok kemandirian belajar sedang tidak lebih baik dari kemampuan berpikir kritis pada kelompok kemandirian belajar tinggi. Berikut adalah jawaban pada soal dan indikator yang sama untuk dianalisis dari salah satu siswa kelompok kemandirian belajar sedang. 


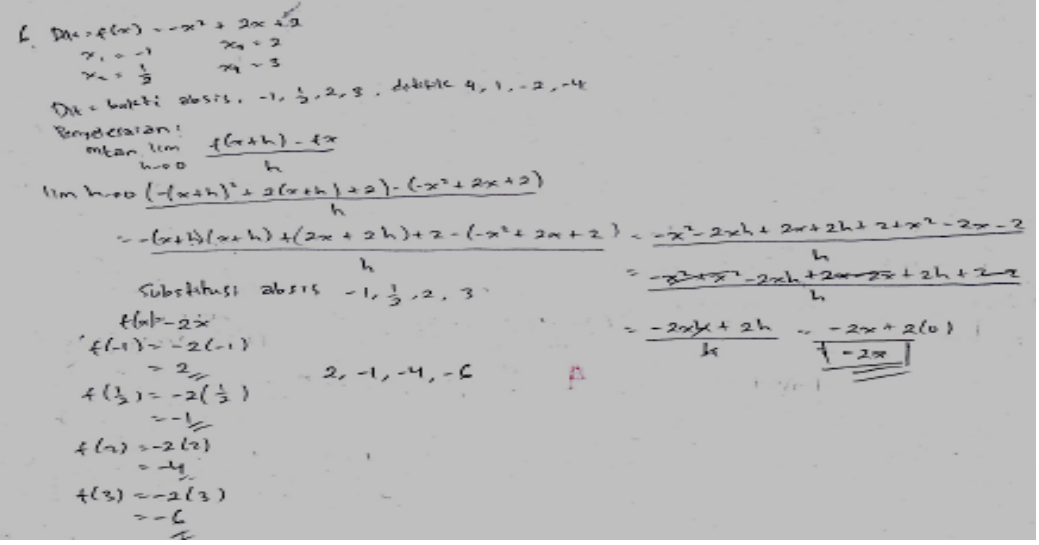

Gambar 2. Jawaban Siswa Kelompok Kemandirian Belajar Sedang

Berdasarkan jawaban yang dituliskan siswa tersebut dapat dianalisis bahwa siswa tersebut sudah mampu mengidentifikasi masalah yang dipertanyakan dalam soal tersebut. Siswa dengan kemandirian belajar sedang sudah mampu mengusulkan dan menyampaikan ide-ide/ konsep yang berkaitan untuk menjawab soal tersebut. Namun dalam proses penyelesaian masalah pada soal tersebut, siswa mempunyai masalah dengan pengoperasian algoritma yang harus diselesaikan sehingga hasil yang yang didapat siswa kurang tepat, dan dalam siswa belum mampu dalam tahap klarifikasi dan tahap penyimpulan. Dengan demikian siswa pada kelompok kemandirian belajar sedang dapat dikatakan memiliki kemampuan berpikir kritis yang cukup. Supaya siswa lancar dan teliti dalam melakukan algoritma, guru dapat membantu dengan memberikan bimbingan yang menuntun siswa dalam menganalisis kesalahannya dan memperbaiki kesalan yang terjadi serta dengan memberikan bimbingan dalam penekanan dalam penerapan konsep matematika. Pada dasarnya, peran guru tidak hanya memberikan informasi saja tetapi yang lebih penting memahami apa yang dipikirkan siswa dan membantu siswa berpikir dan belajar dalam menemukan pengetahuannya (Budiyanto \& Rohaeti, 2012).

\section{c. Analisis Kemampuan Berpikir Kritis Siswa dengan Kemandirian Belajar Rendah}

Selanjutnya berdasarkan Tabel 3. juga menunjukkan bahwa tidak semua siswa yang memiliki kemandirian belajar rendah memiliki skor kemampuan berpikir kritis matematis yang rendah. Namun, jika dillihat dari skor rata-rata yang dimiliki siswa kemandirian belajar rendah sebesar 15,45. Hal tersebut menjelaskan bahwa skor rata-rata yang dicapai siswa dengan kemandirian belajar rendah berada di bawah hasil skor rata-rata siswa kelompok kemandirian belajar tinggi dan sedang.

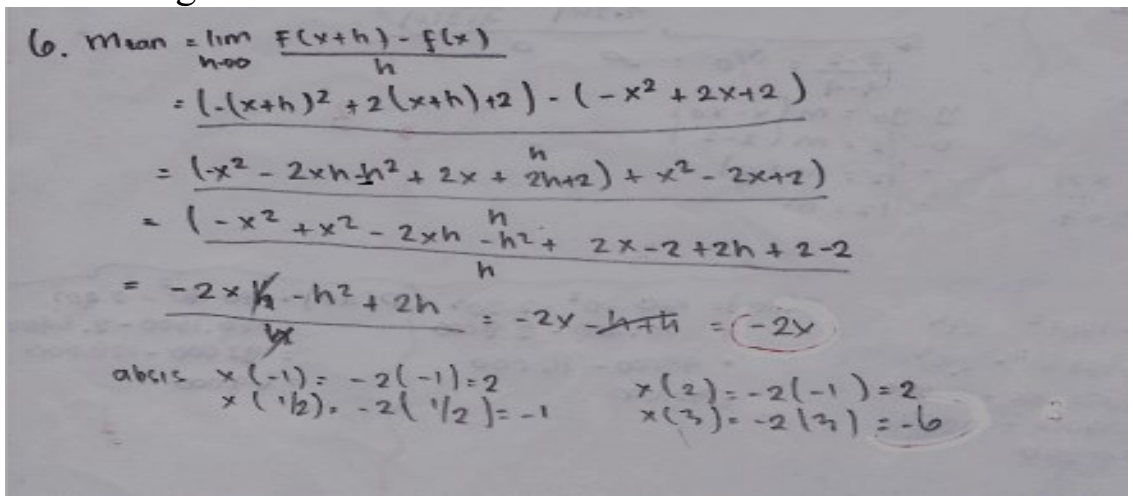

Gambar 3. Jawaban Siswa Kelompok Kemandirian Belajar Rendah 
Berdasarkan Gambar 3. yang merupakan hasil jawaban salah satu siswa kelompok kemandirian belajar rendah dalam menjawab soal dan indikator yang sama dengan kelompok kemandirian belajar tinggi dan sedang. Dari hasil penjabaran yang dijawab siswa dapat dianalisis bahwa siswa dengan kemandirian belajar sedang, belum mampu dalam mengidentifikasi apa yang ditanyakan, diketahui dan strategi untuk menjawab soal tersebut. Kemudian, terdapat kesalah dalam proses algoritma tersebut sehingga hasil yang diperoleh terjadi kesalahan. Siswa dengan kemandirian belajar sedang belum mampu untuk menyelesaikan permasalahan yang terdapat dalam soal. Dengan demikian, siswa dengan kemandirian belajar rendah masih membutuhkan banyak bimbingan dalam menyelesaikan masalah. Maka dari itu untuk membantu siswa dalam menyelesaikan kesulitannya dalam menemukan, guru dapat menggunakan inisiatif seperti memberikan scaffolding berupa dorongan dan petunjuk (Kurniasih, 2012). Pada dasarnya, peran guru sebagai mediator dan fasilitator dalam mengembangkan kemampuan berpikir siswa (Budiyanto \& Rohaeti, 2012).

\section{KESIMPULAN}

Berdasarkan hasil penelitian dan pembahasan, diperoleh simpulan sebagai berikut: (1) kemampuan berpikir kritis matematis siswa kelas XI melalui pembelajaran dengan pendekatan metakognitif lebih baik dari kemampuan berpikir kritis matematis siswa melalui pembelajaran biasa. (2) Kemandirian belajar siswa kelas XI melalui pembelajaran dengan menggunakan pendekatan metakognitif berpengaruh positif terhadap kemampuan berpikir kritis matematis siswa (3) Siswa pada kelompok kemandirian belajar tinggi sudah kemampuan berpikir kritis yang baik hal tersebut ditinjau dari jawab siswa dalam mengidentifikasi masalah, menggunakan strategi, melakukan algoritma dan menarik kesimpulan. Siswa pada kelompok kemandirian belajar sedang sudah dikatakan cukup pada tahap penyelesaian masalah pada soal, siswa masih mengalami kekeliruan dalam algoritman sehingga menghasilkan hasil dan kesimpulan yang kurang tepat. Siswa pada kemandirian belajar rendah hanya mampu menentukan strategi untuk menyelesaikan permasalahan.

\section{DAFTAR PUSTAKA}

Budiyanto, A. ., \& Rohaeti, E. E. (2012). Mengembangkan Kemampuan Berpikir Kreatif dan Kemandirian Belajar Siswa SMA melalui Pembelajaran Berbasis Masalah. Ifinity Journal Ilmiah Program Studi Matematika STKIP Siliwangi Bandung, 1(1), 22-26.

Chrissanti, M. I., \& Widjajanti, D. B. (2015). Keefektifan Pendekatan Metakognitif Ditinjau dari Prestasi Belajar, Kemampuan Berpikir Kritis, dan Minat Belajar Matematika. Jurnal Riset Pendidikan Matematika, 2(1), 51-62.

Fachrurazi. (2011). Penerapan Pembelajaran Berbasis Masalah untuk Meningkatkan Kemampuan Berpikir Kritis dan Komunikasi Matematis Siswa Sekolah Dasar. Jurnal UPI, Edisi Khus(1), 76-89.

Hendriana, H., Sumarmo, U., \& Rohaeti, E. E. (2013). Kemampuan Komunikasi Matematik Serta Kemampuan dan Disposisi Berpikir Kritis Matematik. Delta-Pi: Jurnal Matematika Dan Pendidikan Matematika, 2(1), 35-45.

Hidayat, W. (2011). Meningkatkan Kemampuan Berpikir Kritis dan Kreatif Matematik Siswa Melalui Pembelajaran Kooperatif Think-Talk-Write (TTW) (Doctoral dissertation, Universitas Pendidikan Indonesia). 
Hidayat, W. (2012). Meningkatkan Kemampuan Berpikir Kritis dan Kreatif Matematik Siswa SMA Melalui Pembelajaran Kooperatif Think-Talk-Write (TTW). In Seminar Nasional Penelitian, Pendidikan dan Penerapan MIPA.

Hidayat, W., \& Sumarmo, U. (2013). Kemampuan Komunikasi dan Berpikir Logis Matematik Serta Kemandirian Belajar. Delta-Pi: Jurnal Matematika Dan Pendidikan Matematika, 2(1), 1-14.

Iskandar, S. M. (2014). Pendekatan Keterampilan Metakognitif dalam Pembelajaran Sains di Kelas. Erudio, 2(2), 13-20.

Jumaisyaroh, T., Napitupulu, E. E., \& Hasratuddin. (2014). Peningkatan Kemampuan Berpikir Kritis Matematis dan Kemandirian Belajar Siswa SMP melalui Pembelajaran Berbasis Masalah. Jurnal Kreano, 5(2), 157-169.

Kurniasih, A. W. (2012). Scaffolding sebagai Alternatif Upaya Meningkatkan Kemampuan Berpikir Kritis Matematika. Jurnal Kreano, 3(2), 113-124.

Kemendikbud. (2013). Handout Pelatihan Kurikulum 2013. Jakarta: Kemendikbud.

Noordyana, M. A. (2016). Meningkatkan Kemampuan Berpikir Kritis Matematis Siswa melalui Pendekatan Metacognitive Instruction. Mosharafa: Jurnal Pendidikan Matematika, 5(21), 120-127.

Noto, M. S., Tonah, \& Hernati. (2015). Efektivitas Pendekatan Metakognitif Terhadap Kemandirian Belajar dan Berpikir Kritis Matematis Siswa. Jurnal Penelitian Dan Pembelajaran Matematika (JPPM), 8(1), 47-52.

Rohaeti, E. E. (2010). Critical and Creative Mathematical Thinking of Junior High School Students. Educationist, IV(2), 99-106.

Solikhah, N., Winarti, E. R., \& Kurniasih, A. W. (2014). Keefektifan Model Guided Inquiry dengan Pendekatan Keterampilan Metakognitif terhadap Kemampuan Pemecahan Masalah. Jurnal Kreano, 5(1), 18-25.

Sumarmo, U., Hidayat, W., Zukarnaen, R., Hamidah, M., \& Sariningsih, R. (2012). Kemampuan dan Disposisi Berpikir Logis, Kritis, dan Kreatif Matematik (Eksperimen terhadap Siswa SMA Menggunakan Pembelajaran Berbasis Masalah dan Strategi Think-Talk-Write). Jurnal Pengajaran MIPA, 17(1), 17-33.

Tresnawati, T., Hidayat, W., \& Rohaeti, E. E. (2017). Kemampuan Berpikir Kritis Matematis dan Kepercayaan Diri Siswa SMA. Symmetry: Pasundan Journal of Research in Mathematics Learning and Education, 2(2), 39-45.

Yuliani, A. (2015). Meningkatkan Kemampuan Komunikasi Matematik pada Mahasiswa melalui Pendekatan Contextual Teaching Learning (CTL). Infinity Journal Program Studi Matematika STKIP Siliwangi Bandung, 4(1), 1-9.

Susilawati, W. (2014). Belajar \& Pembelajaran Matematika. Bandung: CV. Insan Mandiri. 